Journal of The Electrochemical Society, 2007, Volume 154, Issue 1, Pages C36-C42

ISSN: (print 0013-4651)(online 1945-7111)

DOI: $10.1149 / 1.2387060$

http://scitation.aip.org/JES

http://scitation.aip.org/getpdf/servlet/GetPDFServlet?filetype=pdf\&id=JESOAN000154000001000C36000001\&idty

pe $=$ cvips

(C) The Electrochemical Society, Inc. 2007. All rights reserved. Except as provided under U.S. copyright law, this work may not be reproduced, resold, distributed, or modified without the express permission of The Electrochemical Society (ECS). The archival version of this work was published in Journal of The Electrochemical Society, 2007, Volume 154, Issue 1, Pages C36-C42

\title{
Effect of Noble Element Alloying on Passivity and Passivity Breakdown of Ni
}

\section{Yeong Ho Kim and G. S. Frankel}

Department of Materials Science and Engineering, Fontana Corrosion Center, The Ohio State University

\begin{abstract}
Welding of stainless steels can generate welding fumes containing carcinogenic hexavalent chromium $\left(\mathrm{Cr}^{+6}\right)$. To mitigate this problem, a new Ni-Cu-Pd welding consumable alloy has been developed. The addition of a small amount of $\mathrm{Cu}$ and $\mathrm{Pd}$ in $\mathrm{Ni}$ enhances the galvanic compatibility of $\mathrm{Ni}$ with stainless steels and improves its localized corrosion behavior. In this paper, the artificial pit electrode technique and $\mathrm{X}$-ray photoelectron spectroscopy were used to study the benefits of $\mathrm{Cu}$ and $\mathrm{Pd}$ alloying. The passive film on $\mathrm{Ni}-10 \mathrm{Cu}-1 \mathrm{Pd}$ alloy mainly consisted of outer $\mathrm{Ni}$-hydroxide and inner oxide, and the noble elements $\mathrm{Pd}$ and $\mathrm{Cu}$ apparently did not contribute to the formation of the passive film. However, Pd catalyzed the reduction of $\mathrm{Cu}$ at the bottom of artificial pits, which enhanced the cathodic reaction and thus ennobled the protection potential, making stable pit growth more difficult. This catalytic effect of Pd also prevented the propagation of deep pits in a test using a thin foil crevice sample.
\end{abstract}

During welding of stainless steels (SS), the evaporation and oxidation of $\mathrm{Cr}$ from the molten weld pool can result in the generation of carcinogenic hexavalent chromium $\left(\mathrm{Cr}^{+6}\right)$ in the welding fume. ${ }^{1,2}$ The U.S. Occupational Safety and Health Administration recently issued a new standard for occupational exposure to hexavalent chromium containing a substantial reduction in the permissible exposure limit, which will make it difficult to weld SS in locations that are not extremely well-ventilated. ${ }^{3,4}$ To reduce the emission of $\mathrm{Cr}^{+6}$ from weld fumes, a $\mathrm{Cr}$-free consumable has been developed for welding austenitic stainless steel ${ }^{5,6}$ The resulting welds in type 304L SS exhibit mechanical properties and corrosion resistance comparable to welds made with commonly used Cr-bearing consumables.

Because the new consumable has a different chemical composition than the stainless steel base plate to be welded, it is important to consider the effects of galvanic interaction on the localized corrosion behavior of the new consumable. Therefore, two major criteria were established to develop a new weld metal for stainless steel: ${ }^{5}$

1. The breakdown and repassivation potentials of the weld metal should be higher than the corrosion potential of the stainless steel base metal in environments of interest to prevent localized attack of the weld metal.

2. The corrosion potential of the weld metal should be slightly higher than that of the stainless steel base metal so that the weld metal is cathodically protected.

$\mathrm{Ni}-\mathrm{Cu}$ alloys initially were selected based on their galvanic compatibility with types 304 
and 316 SS in chloride environments. ${ }^{5}$ 304L SS was welded with Monel filler metal, which contains 28-34 wt $\% \mathrm{Cu}$, to create high-quality welds with no cracks ${ }^{5}$ However, segregated regions rich in $\mathrm{Cu}$ were weak spots for corrosion susceptibility in the welds ${ }^{5}$ Subsequent work on alloys with lower $\mathrm{Cu}$ content led to the selection of $\mathrm{Ni}-10 \mathrm{wt} \% \mathrm{Cu}-1 \mathrm{wt} \% \mathrm{Pd}$, which had higher breakdown potential than Monel (though not as high as 304 SS), higher repassivation potential, and slightly higher OCP than 304 SS, and no localized corrosion observed after long term exposure in $0.1 \mathrm{M} \mathrm{NaCl}$. The corrosion properties of the newly developed alloy satisfy the design criteria for a $\mathrm{Cr}$-free filler metal for welding of $304 \mathrm{SS} .{ }^{6}$ However, the role of $\mathrm{Pd}$ and $\mathrm{Cu}$ on the improvement of the corrosion properties has not been clearly understood.

$\mathrm{Cu}$ has been known to have both beneficial and harmful effects on the corrosion resistance of $\mathrm{Ni}$ alloys. The corrosion resistance of $\mathrm{Ni}-\mathrm{Cu}$ alloys was found to be superior to pure $\mathrm{Ni}$ only in the active region, ${ }^{7}$ and the optimum content of $\mathrm{Cu}$ in $\mathrm{Ni}-\mathrm{Cu}$ alloys to reduce the corrosion rate was about $30 \%$ in $10 \% \mathrm{HCl}, 3 \% \mathrm{NaCl}$, and $10 \% \mathrm{HNO}_{3}{ }^{8}{ }^{8}$ Verink generated experimental Pourbaix diagrams for $\mathrm{Cu}^{-}(0-75 \%) \mathrm{Ni}$ systems in $\mathrm{Cl}^{-}$-containing solutions. With decreasing $\mathrm{Cu}$ content, the passivity of $\mathrm{Ni}-\mathrm{Cu}$ alloys was improved in the acidic region. The higher $\mathrm{Cu}$-containing $\mathrm{Ni}-\mathrm{Cu}$ alloys showed higher weight loss in quiescent seawater after 2 years. ${ }^{10} \mathrm{~A}$ low $\mathrm{Cu}$ content in $\mathrm{Ni}-\mathrm{Cu}$ alloys promoted the formation of a protective $\mathrm{Ni}(\mathrm{OH})_{2}$ film, and the dissolution of $\mathrm{Cu}$ was inhibited in alkaline solution. ${ }^{11}$

Although increasing $\mathrm{Cu}$ content from 30 through $53 \mathrm{wt} \%$ increased the weight loss, it also decreased the pitting depth of Ni-Cu alloys in the same environment ${ }^{12}$ After long term immersion, $\mathrm{Ni}-\mathrm{Cu}$ alloys including Monel 400 showed shallow pits in $\mathrm{Cl}^{-}$-containing environments, whereas Cr-containing alloys such as the stainless steels were deeply attacked at local sites ${ }^{13-17}$ Isaacs and Newman reported that dissolved $\mathrm{Cu}$ was plated out in an artificial pit electrode of type 304 stainless steel in $1 \mathrm{M} \mathrm{NaCl}$ solution. ${ }^{18,19}$ This reaction occurred around $0.27 \mathrm{~V}_{\mathrm{SCE}}$, indicating the reduction of $\mathrm{Cu}$ from $\mathrm{CuCl} 2$. For $\mathrm{Ni}-\mathrm{Cu}$ alloys with $\mathrm{Cu}$ content from 30-50 wt\% in natural seawater, $\mathrm{Cu}$ selectively dissolved as $\mathrm{Cu}^{+}$and $\mathrm{Cu}^{2+}$, and redeposited as a metallic $\mathrm{Cu}^{20}$ The kinetics of the dissolution and reduction of $\mathrm{Cu}$ can play an important role in breakdown and repassivation behavior of $\mathrm{Ni}-\mathrm{Cu}$ alloys.

$\mathrm{Pd}$ is not reactive in many environments and is very effective as a hydrogeneration catalyst. ${ }^{21}$ The doping effect of the noble Pd on the oxide film of Ni-base alloys was reported to improve the life of the oxide in a deaerated aqueous environment at $288^{\circ} \mathrm{C} \cdot{ }^{22-24} \mathrm{Hettiarachchi}^{25}$ also found that $\mathrm{Pd}$ incorporation into the growing oxide on the surface of austenitic stainless steel improved the resistance to stress corrosion cracking (SCC).

The addition of a noble metal such as Au, Pt, or Pd ennobled the open circuit potential (OCP) of type 316 stainless steel in $1 \mathrm{~N} \mathrm{H}_{2} \mathrm{SO}_{4}$ solution for $150 \mathrm{~h}$, and enrichment of these noble metals was detected on the surface. ${ }^{26}$ The ennoblement of the OCP and low passive/active current densities of $\mathrm{Fe}-25 \mathrm{Cr}$ alloy and $\mathrm{Fe}-18 \mathrm{Cr}-10 \mathrm{Ni}$ alloy were also reported with the enrichment of $\mathrm{Pd}$ on the surface by electrolytic deposition. ${ }^{27}$ Potgieter ${ }^{28}$ studied the cathodic modification of alloys with noble metals. The noble metals provided a high exchange current density for the reduction reaction, and then shifted the OCP to the passive range resulting in easy passivation. The effectiveness of this modification was best for platinum group metals (PGMs) and was ordered in terms of high effectiveness from Pt to Pd, Ir, Ru, and Os. Potgieter also found that the noble metal was enriched on the surface after active dissolution and that Mo had a synergetic effect with PGMs. From a study of pure Cr, the addition of $0.1 \%$ Pd lowered the corrosion rate by $10^{5}$ times, as the PGMs blocked the kink sites where active dissolution preferentially occurred. 
In this paper, the influence of $\mathrm{Cu}$ and $\mathrm{Pd}$ on the passivity and passivity breakdown of $\mathrm{Ni}$ is addressed. Passive film composition determined by X-ray photoelectron spectroscopy (XPS), and localized corrosion kinetics determined by artificial pit electrode experiments and proved by a thin foil crevice test, are presented.

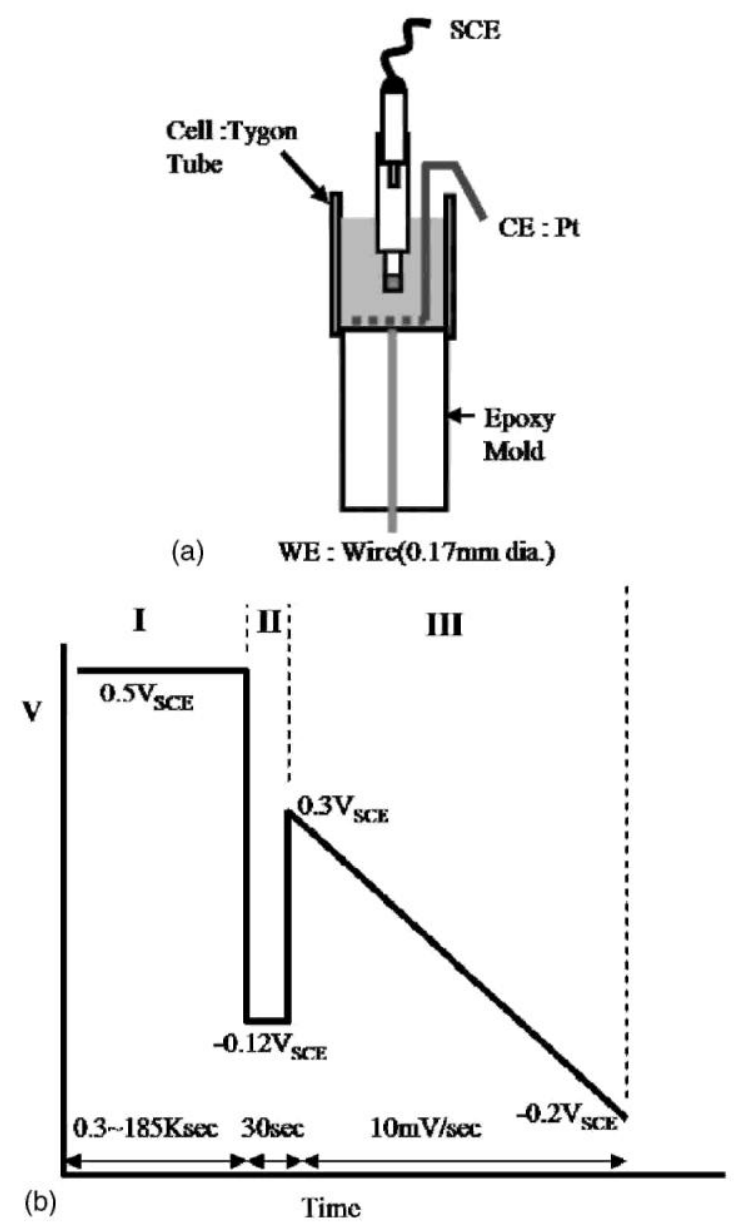

Figure 1. Schematics of (a) the artificial pit electrode and (b) the electrochemical test procedure.

\section{Experimental}

Five $\mathrm{Ni}$ alloys were studied: pure $\mathrm{Ni}, \mathrm{Ni}-10 \mathrm{Cu}, \mathrm{Ni}-1 \mathrm{Pd}, \mathrm{Ni}-30 \mathrm{Cu}$, and $\mathrm{Ni}-10 \mathrm{Cu}-1 \mathrm{Pd}$ (in wt\%). The alloys were melted from pure materials and cast in the shape of small disks. By a series of processes, they were worked to wires with 0.17 or $0.34 \mathrm{~mm}$ diam. The wires were degreased and annealed at $1100^{\circ} \mathrm{C}$ for $1 \mathrm{~h}$ in vacuum-sealed quartz tubes. Finally, they were mounted in epoxy. The details of the artificial pit electrode are shown schematically shown in Fig. 1. The samples were ground to no. 600 grit and then inserted facing upward into a cell that was filled with $0.1 \mathrm{M} \mathrm{NaCl}$. A Pt wire counter electrode and saturated calomel electrode (SCE) reference electrode were used.

Three electrochemical steps in series were used to evaluate the polarization behavior of the artificial pits. First, to make an artificial pit of a specific depth, a constant potential was applied, $0.8 \mathrm{~V}_{\mathrm{SCE}}$ for $\mathrm{Ni}-30 \mathrm{Cu}$ and $0.5 \mathrm{~V}_{\mathrm{SCE}}$ for the rest of the samples. The time to generate a certain pit depth during the potentiostatic test was calculated using Faraday's law on preliminary 
experimental runs. Four different depths of pits on each sample were tested, where the ratio of the pit depth/diameter was in the range of 0.5 to 4.0. The potential was then stepped down to $0.12 \mathrm{~V}_{\mathrm{SCE}}$ for $30 \mathrm{~s}$ to dissolve the salt film in the pit. ${ }^{29}$ Finally, the potential was scanned from $0.3 \mathrm{~V}_{\mathrm{SCE}}$ to $-0.2 \mathrm{~V}_{\mathrm{SCE}}$ at $10 \mathrm{mV} / \mathrm{min}$. The depths of the artificial pits were confirmed after the experiments by observation in an optical microscope and by integration of the current. Some of the wires were extracted by breaking the epoxy mold after the test and then analyzed using

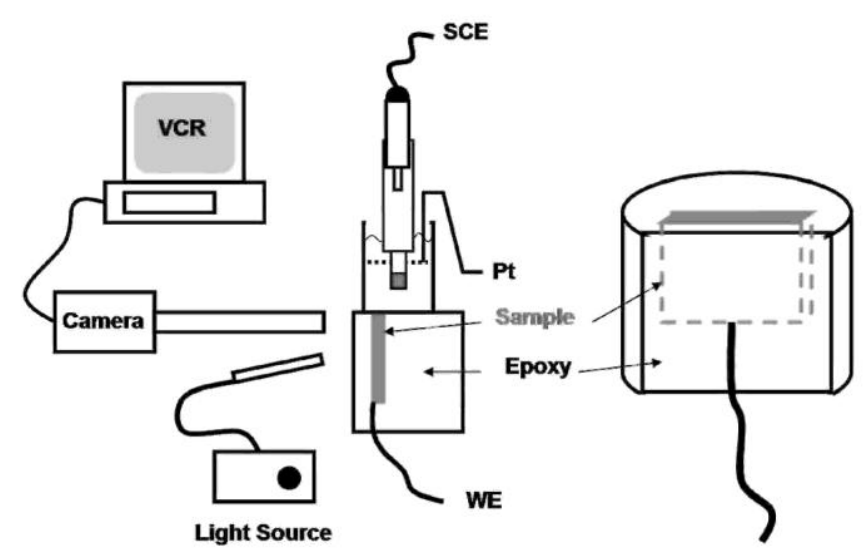

Figure 2. Schematic showing the foil sample with the arrangement of recording and electrochemical equipments.

SEM-EDS. Upward scanned potentiodynamic polarization experiments were performed on some samples with no prior dissolution, so that the surface of the electrode was coplanar with the epoxy mount.

Samples of each alloy $10 \times 10 \mathrm{~mm}$ in size were polarized in $0.1 \mathrm{M} \mathrm{NaCl}$ for $10 \mathrm{~min}$ at 0 $\mathrm{V}_{\mathrm{SCE}}$ where all of the samples were in the passive state. After passivation, the samples were rinsed with distilled water and dried. After sitting in the vacuum chamber for about $16 \mathrm{~h}$, the passive films were analyzed using XPS at $13 \mathrm{kV}$ with monochromated X-rays from an Al target. The sample surface was intermittently sputter-etched using Ar ions for 15 or $30 \mathrm{~s}$. The sputtering rate was about $20 \AA / \mathrm{min}$.

Two alloys, pure $\mathrm{Ni}$ and $\mathrm{Ni}-10 \mathrm{Cu}-1 \mathrm{Pd}$, were prepared as foils for crevice corrosion testing. Homogenized $1 \mathrm{~mm}$ thick plates were polished down to no. 600 grit abrasive paper until reaching a final thickness of $0.17 \mathrm{~mm}$ and electrically connected with a $\mathrm{Cu}$ wire. This foil was embedded in epoxy with one edge of the foil exposed at the top surface of the mold. A side of the epoxy mold parallel to the foil electrode was thinned to about $0.17 \mathrm{~mm}$ by grinding and polished to $1 \mu \mathrm{m}$ to facilitate visual observation of the side of the foil (Fig. 2). The foil edge was exposed vertically in a cell containing $0.1 \mathrm{M} \mathrm{NaCl}$ and a potential of $0.5 \mathrm{~V}_{\mathrm{SCE}}$ was applied for 6 $h$. The configuration of the electrodes and applied potential were the same as those used as in the artificial pit electrode experiments. Furthermore, the foil thickness was the same as the diameter of the wires in the artificial pit electrode. The advantage of the foil crevice electrode was that it allowed observation of the change in topography of the surface during polarization. The side view of the foil sample during propagation of the localized attack downward from the foil edge was recorded using a video camera and VCR.

\section{Results}


XPS analysis - XPS analysis was used to evaluate the composition of the prepassivated alloy surfaces. The $\mathrm{O} 1 \mathrm{~s}$ spectra (not shown) indicated that the outermost surface of the passive film for all the tested $\mathrm{Ni}$ alloys consisted primarily of hydroxide, and that the inner part of the passive film was mixed oxide and hydroxide. The $\mathrm{Pd} 3 \mathrm{~d}_{5 / 2}, \mathrm{Cu} 2 \mathrm{p}_{3 / 2}$ and $\mathrm{Cu} \mathrm{LMM}$ Auger peaks were analyzed to assess the oxidation states of $\mathrm{Pd}$ and $\mathrm{Cu}$. These elements mainly existed in the unoxidized metallic state, but small amounts of $\mathrm{PdO}$ and $\mathrm{CuO}$ were detected in the outermost region, Fig. 3.

The height of the $\mathrm{O} 1 \mathrm{~s}, \mathrm{Cu} 2 \mathrm{p}_{3 / 2}$, and $\mathrm{Pd} 3 \mathrm{~d}_{5 / 2}$ peaks of $\mathrm{Ni}-10 \mathrm{Cu}-1 \mathrm{Pd}$ alloy were analyzed as a function of depth during sputter profiling, Fig. 4. It is possible that some $\mathrm{Cu}^{+1}$ is included in the analysis for $\mathrm{CuO}$, but the total amount of oxidized $\mathrm{Cu}$ was small. Figure 3 shows that both metallic $\mathrm{Cu}$ and $\mathrm{Pd}$ were present in the passive film, but in depleted concentrations relative to the content in the bulk alloy.
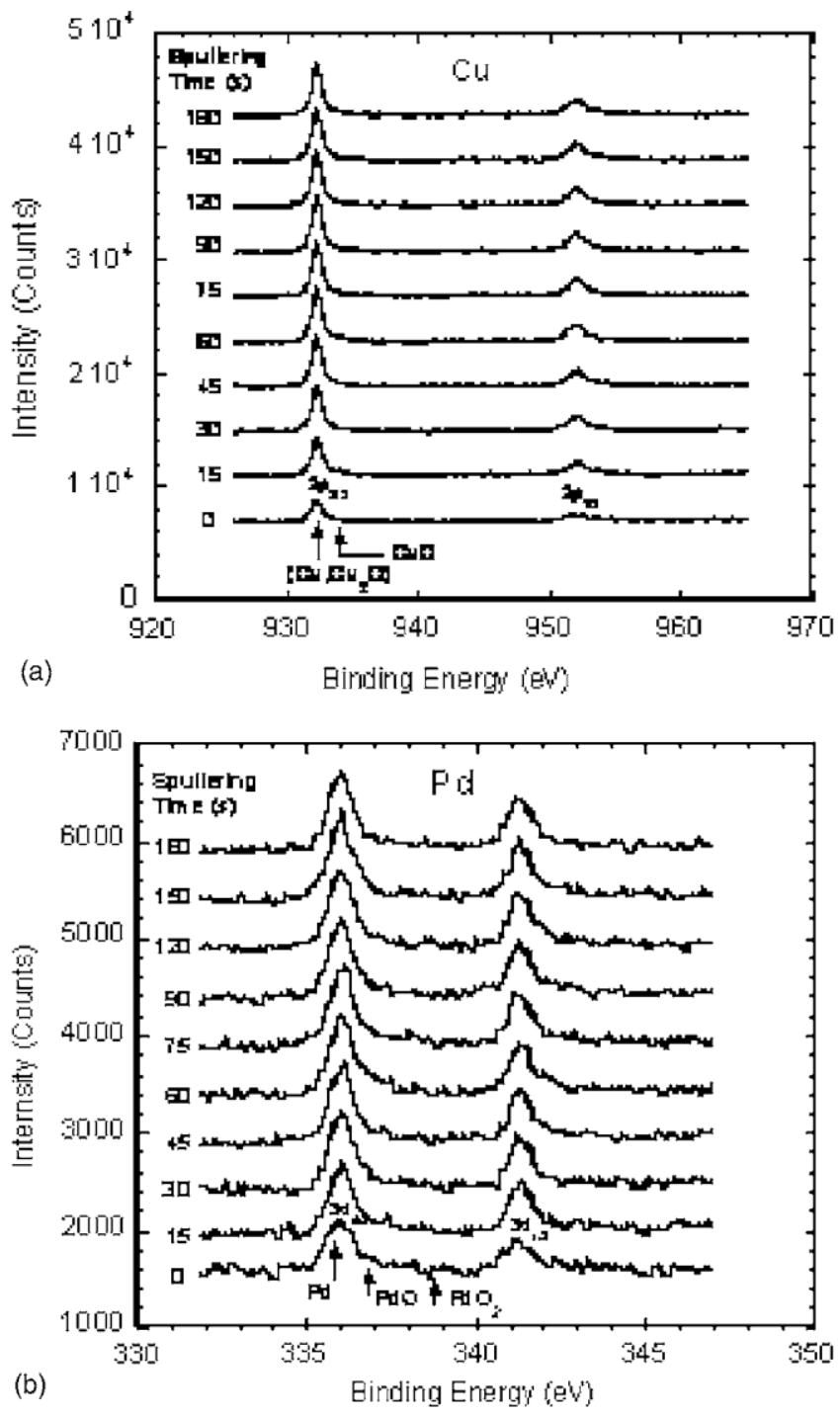

Figure 3. XPS results of (a) $\mathrm{Cu} 2 \mathrm{p}$ and (b) Pd 3d peaks of Ni-10Cu-1Pd alloy, showing some involvement of $\mathrm{Cu}$ and $\mathrm{Pd}$ in the outer layer. 
Artificial pit electrode studies - Figure 5 shows the polarization curves for artificial pit electrodes of $0.17 \mathrm{~mm}$ diam and similar depths in the range of $0.3-0.4 \mathrm{~mm}$, obtained by scanning downward from $0.3 \mathrm{~V}_{\mathrm{SCE}}$ as described above. The pit current decreased during the reverse scan as the potential decreased. After reaching a zero-current potential, the current changed polarity becoming negative. The cessation of artificial pit growth can be accomplished by two different processes-repassivation or deactivation. Repassivation occurs when the current density decreases during downward potential scanning and the conditions at the pit bottom change to the point at which the active state can no longer be sustained so the surface repassivates. ${ }^{30-32}$ This repassivation process is accompanied by a sharp drop in current density to a lower passive current density. The cessation of pit growth during downward scanning can also result from a deactivation process in which the potential is scanned through the corrosion potential of the electrode surface in the pit environment such that the net current becomes cathodic. ${ }^{30,31}$ The term "protection potential" is generic and encompasses both repassivation and deactivation.

Cessation of the artificial pit electrodes in this study seemed to be a deactivation process occurring as the result of an increase in the cathodic reaction. The addition of $10 \% \mathrm{Cu}$ decreased the anodic current relative to pure $\mathrm{Ni}$ and increased the cathodic current in the
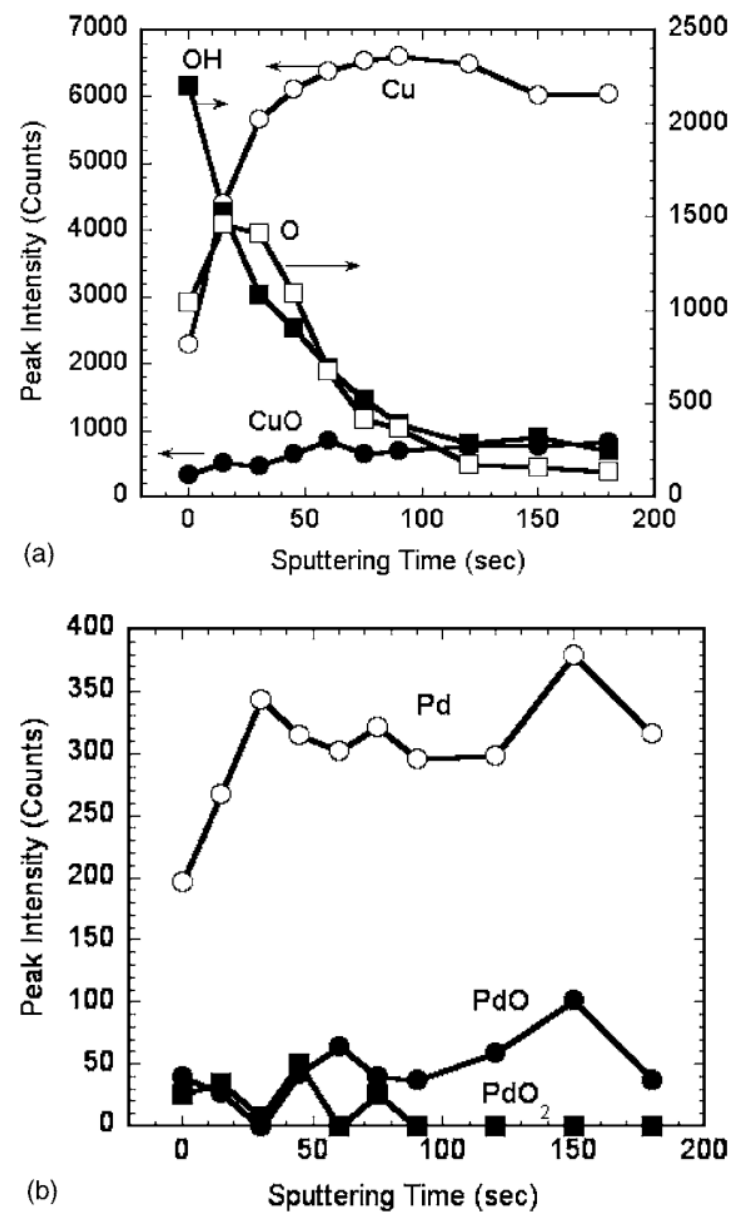

Figure 4. XPS depth-profile results of Ni-10Cu-1Pd alloy after the passivation at $0 \mathrm{~V}_{\mathrm{SCE}}$ for $10 \mathrm{~min}$. (a) Intensity of $\mathrm{Cu} 2 \mathrm{p}_{3 / 2}, \mathrm{CuO} 2 \mathrm{p}_{3 / 2}$ (referred to left axis), $\mathrm{O} 2 \mathrm{p}_{3 / 2}$ and $\mathrm{OH} 2 \mathrm{p}_{3 / 2}$ (referred to right axis). (b) Intensity of $\mathrm{Pd} 3 \mathrm{~d}_{5 / 2}, \mathrm{PdO} 3 \mathrm{~d}_{5 / 2}$, and $\mathrm{PdO}_{2} 3 \mathrm{~d}_{5 / 2}$. 


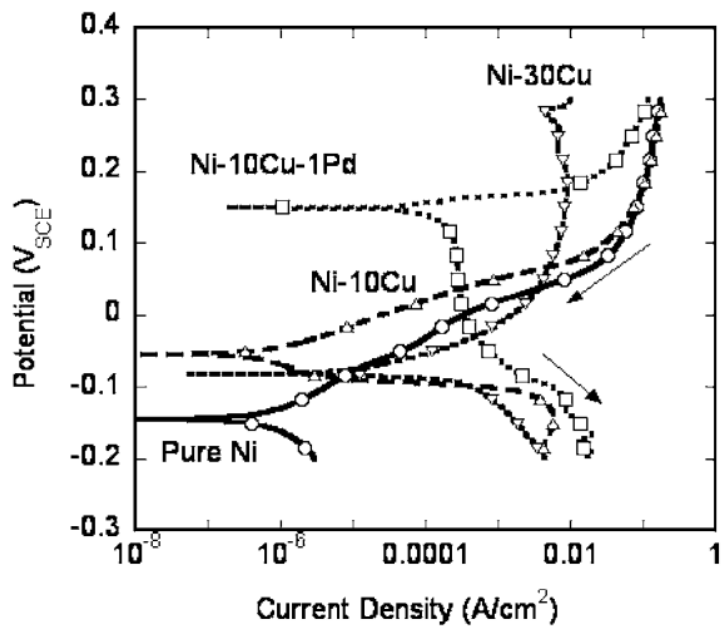

Figure 5. Polarization curves for artificial pit electrodes with $0.17 \mathrm{~mm}$ diam and depths in the range of 0.3 to $0.4 \mathrm{~mm}$.

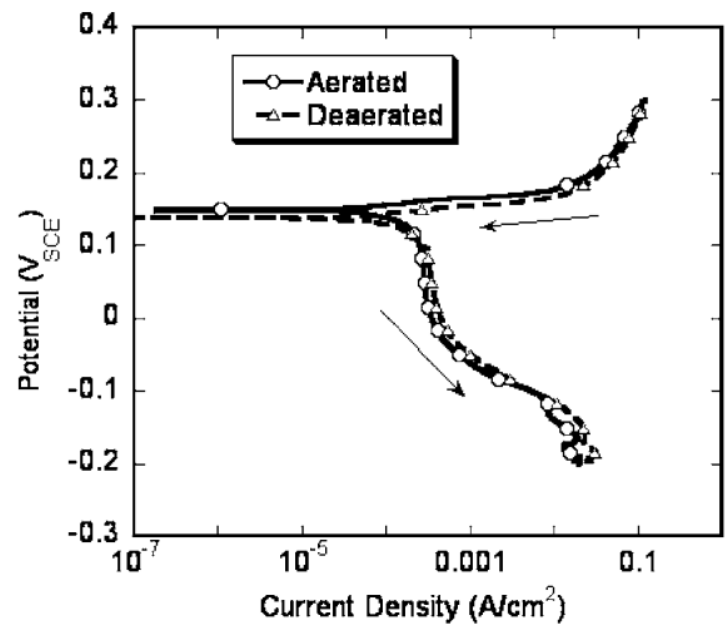

Figure 6. Pit polarization curves for Ni-10Pd-1Pd artificial pits of depth $0.34 \mathrm{~mm}$ in aerated and deaerated $0.1 \mathrm{M} \mathrm{NaCl}$ solutions.

pit, resulting in deactivation and an increase in the protection potential. The addition of more $\mathrm{Cu}$, to $30 \mathrm{wt} \%$, provided no further benefit. However, the addition of even $1 \mathrm{wt} \% \mathrm{Pd}$ to $\mathrm{Ni}-10 \mathrm{Cu}$ resulted in a large increase in protection potential as a result of a large increase in the cathodic reaction rate inside the pit. Noble metal alloys have previously been found to cause such increases in cathodic reaction rates. $^{21,33}$

The cathodic reaction in the artificial pit might come from reduction of dissolved oxygen molecules, protons, or metallic ions. Figure 6 shows pit polarization curves for $\mathrm{Ni}-10 \mathrm{Cu}-1 \mathrm{Pd}$ in deaerated and aerated solutions. The curves are identical, indicating that the ca-thodic reaction was not oxygen. This was expected, as oxygen should be depleted in the constricted crevice. Furthermore, the protection potential of Ni-10Cu-1Pd alloy was $0.15 \mathrm{~V}_{\mathrm{SCE}}$, which is much higher than the reversible potential of $\mathrm{H}^{+} / \mathrm{H}_{2}$, indicating that hydrogen evolution is probably not the 
reduction process. However, this potential is very close to the standard equilibrium potential of $\mathrm{Cu}^{2+} / \mathrm{Cu}, 0.337 \mathrm{~V}_{\mathrm{NHE}}$ or about $0.1 \mathrm{~V}_{\text {SCE }}$.

In an effort to assess the possibility of cupric ion reduction in the artificial pit electrodes, measurements were made in environments with purposeful additions of cupric ions at a concentration of $0.5 \mathrm{M}$

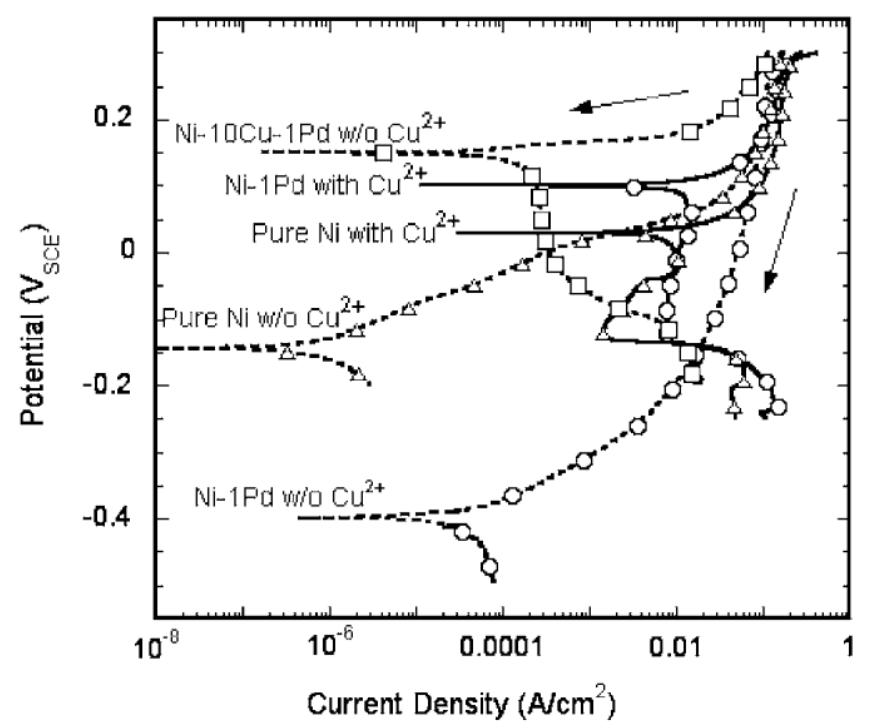

Figure 7. Artificial pit polarization curves for various alloys in $0.1 \mathrm{M} \mathrm{NaCl}$ with or without the addition of $0.5 \mathrm{M}$ cupric ion.

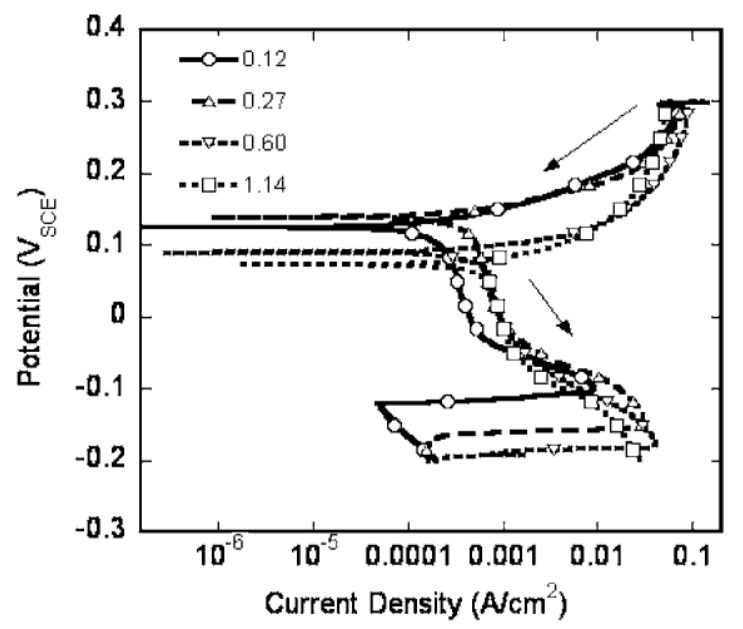

Figure 8. Effect of the pit depth on the polarization curves for Ni-10Cu-1Pd artificial pit electrodes of diameter $0.34 \mathrm{~mm}$. The numbers refer to pit depth in $\mathrm{mm}$.

using samples with no $\mathrm{Cu}$ content, Fig. 7. The protection potential for the alloy Ni-1Pd was 0.1 $\mathrm{V}_{\mathrm{SCE}}$ in $0.5 \mathrm{M} \mathrm{CuCl}_{2}+0.1 \mathrm{M} \mathrm{NaCl}$ solution, but only $-0.4 \mathrm{~V}_{\mathrm{SCE}}$ in $0.1 \mathrm{M} \mathrm{NaCl}$ solution without cupric addition. The protection potential for $\mathrm{Ni}-1 \mathrm{Pd}$ in the cupric-containing solution was close to that for $\mathrm{Ni}-10 \mathrm{Cu}-1 \mathrm{Pd}$ alloy in $0.1 \mathrm{M} \mathrm{NaCl}$ solution with no cupric addition. Pure Ni also 
showed a very high protection potential in cupric-containing solution, but it was lower than that of Ni-1Pd. The protection potentials for both pure $\mathrm{Ni}$ and $\mathrm{Ni}-1 \mathrm{Pd}$ in $0.1 \mathrm{M} \mathrm{NaCl}$ with no cupric ion were much lower. These observations suggest that the higher rate of the ca-thodic reaction for $\mathrm{Ni}-10 \mathrm{Cu}-1 \mathrm{Pd}$ artificial pits in chloride solution was associated with the reduction of the copper ions that were previously dissolved from the alloy into the pit environment. Further evidence for this is given by Fig. 8, which shows the effect of pit depth on the backward-scanned polarization curves for $\mathrm{Ni}-10 \mathrm{Cu}-1 \mathrm{Pd}$ artificial electrodes of diameter $0.34 \mathrm{~mm}$. For shallow artificial pit electrodes, a sharp decrease in cathodic current of about two orders of magnitude was observed during the back scan. The potential at which this decrease occurred decreased with increasing pit depth. The deepest pit, $1.14 \mathrm{~mm}$ deep, was not scanned down far enough to exhibit the current decrease. The sharp decrease is apparently associated with depletion of copper ion from the pit environment. Deeper pits contain a larger reservoir of the dissolved species, and the depletion occurs at a lower potential, after more cathodic charge has passed and more deposition has occurred.

After the first potentiostatic step at $0.5 \mathrm{~V}_{\mathrm{SCE}}$ in $0.1 \mathrm{M} \mathrm{NaCl}$ solution, the epoxy mold around a $\mathrm{Ni}-10 \mathrm{Cu}-1 \mathrm{Pd}$ sample was mechanically broken and the alloy wire was extracted. The top surface of the wire, which was actually the bottom of the artificial pit electrode, was coated with carbon and analyzed using scanning electron microscopy-energy-dispersive spectroscopy (SEM-EDS), Fig. 9. For Ni-10Cu-1Pd with a pit depth of $0.34 \mathrm{~mm}$, the surface was flat with some scattered crystallographic pits. Local enrichment of $\mathrm{Pd}$ and $\mathrm{Cu}$ was detected at the same sites across the pit surface. A small amount $\mathrm{Cl}$ was also detected at those sites. It has been reported that $\mathrm{Cu}$ and $\mathrm{Cl}$ can form compounds in pits. ${ }^{18,19}$

To monitor the localized attack morphology, a dissolving thin foil crevice sample was viewed from the side face as shown in Fig. 2. A constant potential was applied to pure Ni and $\mathrm{Ni}-10 \mathrm{Cu}-1 \mathrm{Pd}$ alloy for $6 \mathrm{~h}$ in $0.1 \mathrm{M} \mathrm{NaCl}$ solution while recording the morphology of the foil from the side. For pure $\mathrm{Ni}$ at $0.5 \mathrm{~V}_{\mathrm{SCE}}$, breakdown occurred at the two edges of the foil after $1 \mathrm{~h}$ and then propagated into the depth. The middle of the foil was unattacked and the surface remained at the position of the original solution/metal (S/M) interface, Fig. 10. For Ni-10Cu-1Pd alloy tested at $0.5 \mathrm{~V}_{\mathrm{SCE}}$, the whole

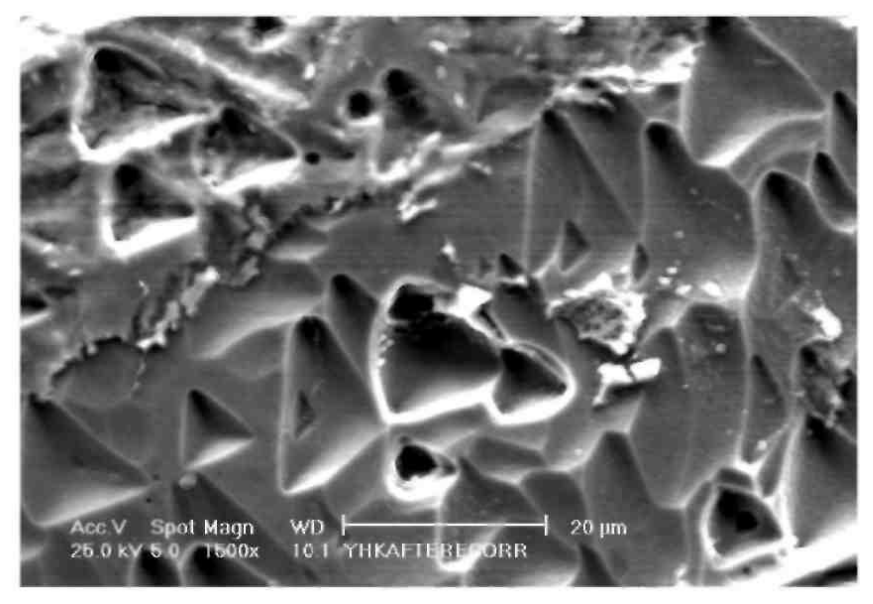

Figure 9. Pit bottom of Ni-10Cu-1Pd after the first step of potentiostatic test at $0.5 \mathrm{~V}_{\mathrm{SCE}}$ showing the flat surface with the scattered crystallographic pitting. 
surface of the foil was attacked after $1 \mathrm{~h}$ and then the S/M interface gradually shifted down with time, Fig. 11. The S/M interface still remained almost as flat as the attack proceeded by repeated breakdown and fast deactivation of many sites. The Pd addition changed the mode of pit propagation from localized growth of few sites to wide spreading of many sites.

\section{Discussion}

Previous work showed that the alloy $\mathrm{Ni}-10 \mathrm{Cu}-1 \mathrm{Pd}$ exhibited superior resistance to localized corrosion in potentiodynamic testing

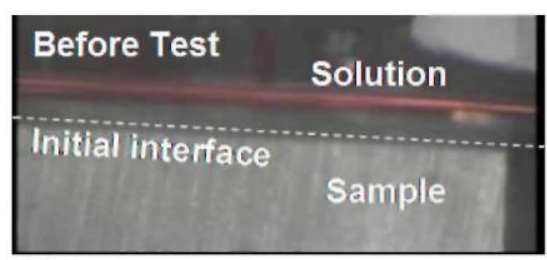

(a)

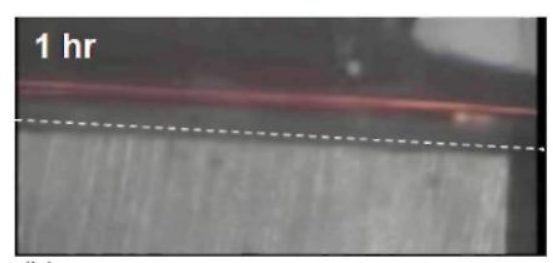

(b)

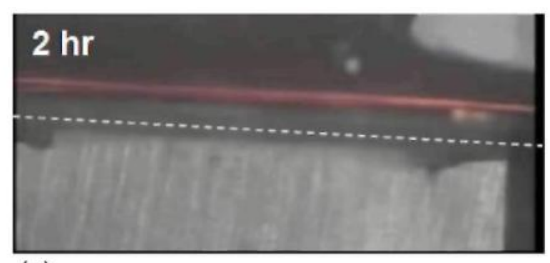

(c)

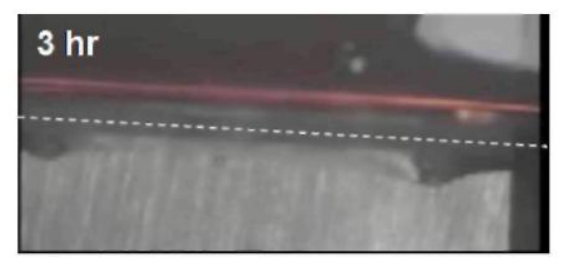

(d)

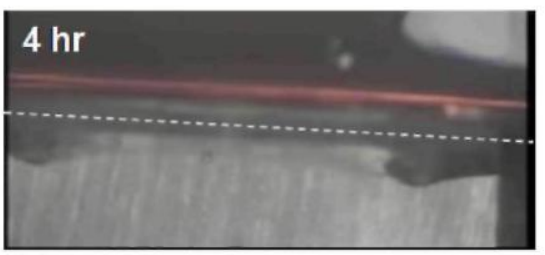

(e)

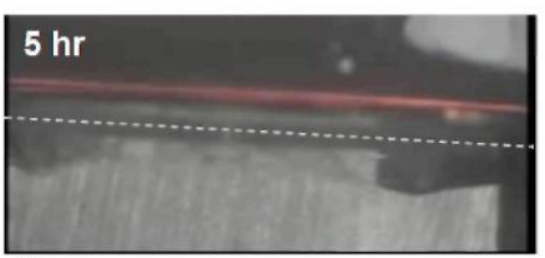

(f)

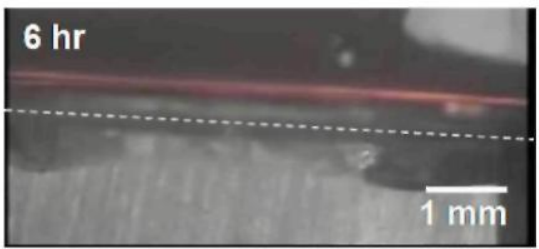

(g)

Figure 10. (Color online) Propagation with time of the localized attack on pure Ni foil at $0.5 \mathrm{~V}_{\mathrm{SCE}}$ in $0.1 \mathrm{M}$ $\mathrm{NaCl}$ solution.

and exposure tests, and is a suitable alloy for use as a Cr-free consumable in the welding of 304 $\mathrm{SS}^{6}{ }^{6}$ The reasons for this corrosion resistance were explored in this work.

The beneficial effects of noble Pd additions on the passivity of other Ni-alloys has been reported previously. ${ }^{22,23}$ However, the results of this study suggest that the addition of $\mathrm{Cu}$ and $\mathrm{Pd}$ to $\mathrm{Ni}$ has little effect on the passive film and that improvement in localized behavior obtained by 
alloying is more related to the effects on the anodic and cathodic kinetics in pits than to improvements in the protectiveness of the passive film.

It was shown that $\mathrm{Ni}$ artificial pit electrodes scanned downward from high potentials exhibit high zero-current potentials when $\mathrm{Cu}$ and $\mathrm{Pd}$ are alloyed at low levels or when cupric ions are introduced into the electrolyte. The cessation of artificial pit growth is considered to be a deactivation process resulting from a dramatic increase in the cathodic kinetics in the pit. The cathodic reaction was shown not to be oxygen reduction or hydrogen evolution and it can be concluded that the primary cathodic reaction in the artificial pit electrodes was reduction of $\mathrm{Cu}$ ions. The great enhancement in the rate of this reaction for the Ni-10Cu-1Pd alloy relative to the $\mathrm{Ni}-\mathrm{Cu}$ binary alloys and the co-location of $\mathrm{Pd}$ and $\mathrm{Cu}$ on the surface of an artificial pit electrode suggest that the $\mathrm{Cu}$ reduction was catalyzed at sites where $\mathrm{Pd}$ was enriched at the surface, perhaps by surface enrichment from the dissolution of $\mathrm{Ni}$ and $\mathrm{Cu}$. The synergism between cupric ions in solution and Pd enrichment on the surface resulted in a strong ennoblement of the deactivation process, which decreased the stability of the pits.

Pd also affects the anodic pit kinetics. Comparison of the artificial pit polarization curves for pure $\mathrm{Ni}$ and $\mathrm{Ni}-1 \mathrm{Pd}$ in the cupric free $0.1 \mathrm{M} \mathrm{NaCl}$ solution (Fig. 7) indicates that in the absence of $\mathrm{Cu}, \mathrm{Pd}$

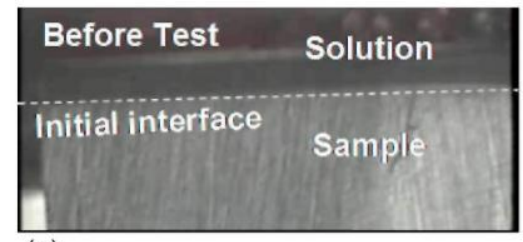

(a)

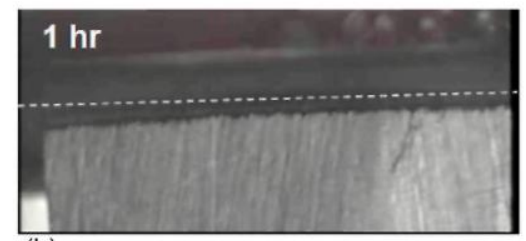

(b)

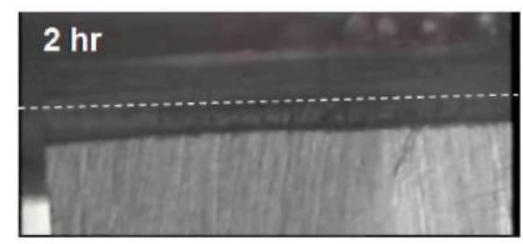

(c)

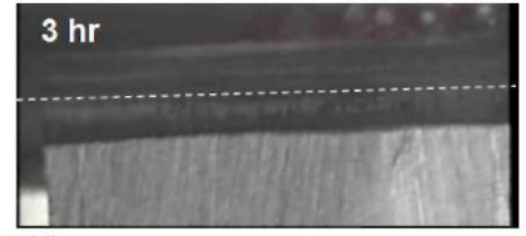

(d)

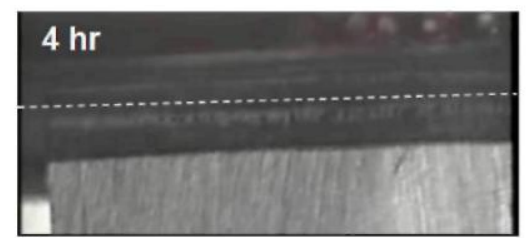

(e)

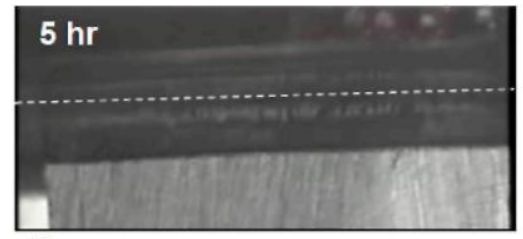

(f)

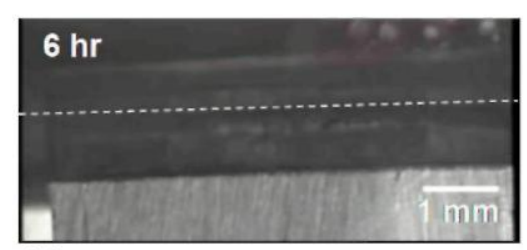

(g)

Figure 11. Propagation with time of the localized attack on Ni-10Cu-1Pd foil at $0.5 \mathrm{~V}_{\mathrm{SCE}}$ in $0.1 \mathrm{M} \mathrm{NaCl}$ solution. 
results in a large increase in the $\mathrm{Ni}$ active dissolution kinetics. In this cupric-free solution, the primary cathodic reaction is probably hydrogen evolution, and there is no obvious effect of the $\mathrm{Pd}$ addition on the rate of this reaction. However, the rate of anodic dissolution at a given potential is increased by many orders of magnitude for the Ni-1Pd alloy. The curves in Fig. 5 indicate that this enhancement of $\mathrm{Ni}$ dissolution by $\mathrm{Pd}$ was not observed for the Ni-10Cu alloy. However, Fig. 8 shows that the anodic portion of the back-scanned polarization curves for Ni$10 \mathrm{Cu}-1 \mathrm{Pd}$ was dependent on the depth of the pit. The deeper pits with depth of 0.6 and $1.14 \mathrm{~mm}$ exhibited much higher dissolution rates at a given potential than the shallow pits with depth of 0.12 and $0.27 \mathrm{~mm}$. It is likely that the extent of $\mathrm{Pd}$ enrichment increased for the deeper pits, so the effect of $\mathrm{Pd}$ on the anodic kinetics in the pits was more evident for the deeper pits. Pd accelerates the rate of anodic dissolution, but this is more than compensated by the strong effect of $\mathrm{Pd}$ on $\mathrm{Cu}$ deposition, which results in a very high pit corrosion potential. The mechanism for $\mathrm{Pd}$ enhancement of Ni dissolution is not understood.

The creation of a deep artificial pit by forced dissolution at high potential results in the formation of a pit environment that could be different than for a pit that grows at a lower opencircuit potential, so the relevance of the artificial pit electrode measurements to pitting at open circuit must be considered. The breakdown and repas-sivation potentials for $\mathrm{Ni}-10 \mathrm{Cu}-1 \mathrm{Pd}$ in 0.1 $\mathrm{M} \mathrm{NaCl}$ were found to be +220 and $+150 \mathrm{mV} \mathrm{SCE}$, respectively. A study of the behavior of Monel-400 (with $\sim 30 \% \mathrm{Cu}$ ) in deaerated chloride solution found that both $\mathrm{Cu}$ (I) and $\mathrm{Cu}$ (II) were generated during anodic dissolution in a wide range of potential, from -350 to $+400 \mathrm{mV}$ $\mathrm{Ag} / \mathrm{AgCl}^{34}$ At potentials above $+150 \mathrm{mV} \mathrm{Ag} / \mathrm{AgCl}(+130 \mathrm{mV} \mathrm{SCE})$, dissolution was dominated by the formation of $\mathrm{Cu}$ (II). Therefore, the environment created during the formation of the recess in the artificial pit electrode should be similar to that formed in pits at the breakdown potential measured in cyclic polarization experiments.

Figure 12 shows polarization curves measured from the cross sections of $0.17 \mathrm{~mm}$ wires that were not pre-dissolved to form deep artificial pit electrodes, i.e., the surfaces of the wires were coplanar with the epoxy mount. The potential was scanned at $10 \mathrm{mV} / \mathrm{min}$ in $0.1 \mathrm{M} \mathrm{NaCl}$ solution, with a vertex current density of $0.5 \mathrm{~mA} / \mathrm{cm}^{2}$.

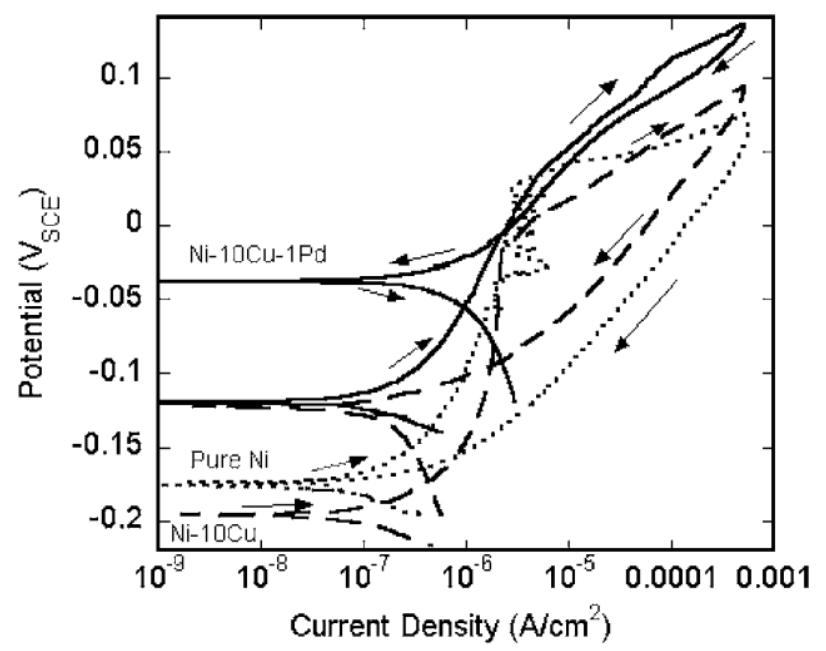

Figure 12. Polarization curves for flat cross section of wire electrodes with $0.17 \mathrm{~mm}$ diameter without predissolution to form deep artificial pits in $0.1 \mathrm{M} \mathrm{NaCl}$. 
The average depth of attack during the cyclic scan was much less than the depth of the artificial pit electrodes and the potentials were much lower. The breakdown potentials for pure Ni, Ni$10 \mathrm{Cu}$, and $\mathrm{Ni}-10 \mathrm{Cu}-1 \mathrm{Pd}$ were all relatively close. Note that the breakdown potentials of the small wire electrodes were lower than for samples with large areas. However, the backscanned portions of the curves for the flat wire cross sections were vastly different from each other. The pure Ni sample exhibited a large hysteresis and a zero-current potential on the backscan equal to the value on the forward scan. The Ni-10Cu-1Pd exhibited a very small hysteresis and much higher zero-current potential on the backscan. The behavior of $\mathrm{Ni}-10 \mathrm{Cu}$ was intermediate. Clearly, the $\mathrm{Cu}$ and $\mathrm{Pd}$ contents exerted a strong influence on these curves, even with relatively small extents of attack.

The general understanding of critical potentials is that localized corrosion can initiate at potentials above the breakdown potential, and it can continue to grow at potentials above the protection potential. ${ }^{35}$ In real applications under open-circuit conditions, localized corrosion initiates when the potential is high, and then the potential drops as a result of the activation at the pit bottom. Therefore, the environment generated in a pit growing at high open-circuit potentials is relevant to the possible cessation of pit growth at lower open circuit potentials.

Newman and Isaacs performed cyclic voltammetry measurements on small Pt wires inserted into an artificial pit electrode made from a commercial 304L SS wire of larger diameter. $^{19}$ They observed oxidation and reduction peaks at -200 and $-350 \mathrm{mV}$ SCE, respectively, which they assigned to the $\mathrm{Cu} / \mathrm{CuCl}_{2}{ }^{-}$redox reaction associated with the $0.33 \% \mathrm{Cu}$ in the alloy. As mentioned above, the protection potential for the Ni-10Cu-1Pd artificial pit electrode is much higher than these values and close to the standard potential for $\mathrm{Cu} / \mathrm{Cu}^{2+}$. The lower protection potential found for the flat $\mathrm{Ni}-10 \mathrm{Cu}-1 \mathrm{Pd}$ wire electrode is still higher than the peaks observed by Newman and Isaacs and might be connected to lower cupric ion concentrations. Our interpretation is that the cathodic reaction for the $\mathrm{Cu}$-containing alloys is the reduction of $\mathrm{Cu}^{2+}$ and that it is relevant to the behavior of these alloys at open circuit conditions.

There have been many studies reporting the superior resistance of $\mathrm{Cu}$-containing $\mathrm{Ni}$ alloys to localized corrosion in chloride environments for more than 30 years. These alloys usually showed much shallower pits than stainless steel even if the first formation of the pits was earlier for $\mathrm{Ni}-\mathrm{Cu}$ alloys than for stainless steels. ${ }^{13-16} \mathrm{Ni}-10 \mathrm{Cu}-1 \mathrm{Pd}$ alloy in this study also showed very shallow pits in the long term crevice corrosion test, compared to type 304L stainless. ${ }^{36}$ This behavior can be explained by the stifling of pit growth by the plating of $\mathrm{Cu}$ from the pit environment.

\section{Conclusions}

The effects of $\mathrm{Cu}$ and $\mathrm{Pd}$ on the passivation and localized corrosion behavior of Ni alloys were investigated using XPS and the artificial pit electrode technique. The following are the important conclusions of this study.

The passive film on $\mathrm{Ni}-10 \mathrm{Cu}-1 \mathrm{Pd}$ alloy consisted of a mixture of oxide and hydroxide, with the outermost layer being mainly hydroxide. Very little $\mathrm{Cu}$ and $\mathrm{Pd}$ were found in the passive film and they were mostly in the metallic state. This small change in the composition of passive film cannot explain the improved resistance to the localized corrosion of $\mathrm{Ni}-\mathrm{Cu}-\mathrm{Pd}$ alloy.

The addition of $1 \mathrm{wt} \% \mathrm{Pd}$ increased the artificial pit electrode protection potential considerably over the whole range of the pit depth studied. This protection potential for the Ni$10 \mathrm{Cu}-1 \mathrm{Pd}$ artificial pit electrode is close to the standard potential for $\mathrm{Cu} / \mathrm{Cu}^{2+}$. 
The improved resistance to the localized corrosion of $\mathrm{Ni}-10 \mathrm{Cu}-1 \mathrm{Pd}$ alloy is attributed primarily to the cessation of pit growth by enhanced reduction of copper ions from the pit environment in the presence of $\mathrm{Pd}$.

\section{Acknowledgments}

Financial support of the Strategic Environmental Research and Development Program (SERDP) through project WP-1415 is greatly appreciated.

The Ohio State University assisted in meeting the publication costs of this article.

\section{References}

1. P.-J. Cunat, Materiaux \& Techniques, 90, 19 (2002).

2. S. B. Mortazavi, Weld. World, 39, 297 (1998).

3. Occupational Exposure to Hexavalent Chromium; Final Rule, Occupational Safety and Health Administration, Department of Labor, Federal Register, Vol. 71, No. 39 (2006).

4. National Occupational Health and Safety Commission, Australian Government Publishing Service, p. 1, Canberra, Australia (1990).

5. Y. H. Kim, G. S. Frankel, J. C. Lippold, and G. Guaytima, Corrosion (Houston), 62, 44 (2006).

6. Y. H. Kim, G. S. Frankel, and J. C. Lippold, Corrosion (Houston), 62, 109 (2006).

7. G. N. Flint and W. Barker, in Society of Chemical Industry, p. FB1, Chemical Engineering Group, London (1964).

8. S. Masaki and K. Hirano, Bosei Kanri, 35, 25 (1991).

9. E. D. Verink, Jr., and I. T. S. Lee, in Third International Congress on Marine Corrosion and Fouling, p. 241, National Bureau of Standards, Gaithersburg, MD (1972).

10. R. B. Niederberger, R. J. Ferrara, and F A. Plummer, Materials Protection and Performance, 9, 18 (1970).

11. A. M. Zaky and F H. Assaf, Br. Corros. J., London, 37, 48 (2002).

12. R. B. Niederberger, R. J. Ferrara, and F A. Plummer, in 26th Conference of Naional Association of Corrosion Engineers, p. 188, NACE, Philadelphia, PA (1970).

13. M. J. Mehta, J. Electrochem. Soc. India, 41-1, 57 (1992).

14. E. A. Baker, in Degradation of Metals, ASTM STP 965, S. W. Dean and T. S. Lee, Editors, p. 125, ASTM, Philadelphia, PA (1988).

15. W. W. Kirk, Materials Performance, 26, 23 (1987).

16. B. S. Phull and R. M. Kain, in Nickel-Cobalt 97 International Symposium, p. 141, Canadian Institute of Mining, Metallurgy, and Petroleum, Sudbury, Ontario (1997).

17. A. I. Asphahani, in Metals Handbook, Vol. 13, 9th ed., L. J. Korb, Editor, p. 641, ASM International, Materials Park, Ohio (1987).

18. H. S. Isaacs and R. C. Newman, in Corrosion Chemistry within Pits, Crevices and Cracks, A. Turnbull, Editor, p. 45, Her Majesty's Stationery Office, London (1984).

19. R. C. Newman and H. S. Isaacs, in Passivity of Metals and Semiconductors, M. Froment, Editor, p. 269, Elsevier Science Publisher B. V, Bombannes, France (1983).

20. A.-M. Beccaria and J. Crousier, Br. Corros. J., London, 24, 49 (1989).

21. J. Edwards, Coating and Surface Treatment Systems for Metals, p. 102, Redwood Books Ltd., Trowbridge, UK (1994).

22. P. L. Andresen, S. Hettiarachchi, Y J. Kim, and T. P. Diaz, U.S. Pat. 5,608,766 (1997).

23. P. L. Andresen, S. Hettiarachchi, Y J. Kim, and T. P. Diaz, U.S. Pat. 5,768,330 (1998).

24. P. L. Andresen, in Sixth International Symposium on Environmental Degradation of Materials in Nuclear Power Systems-Water Reactors, R. E. Gold and E. P. Simonen, Editors, p. 245, TMS, San Diego, CA (1993).

25. S. Hettiarachchi, U.S. Pat. 5,448,605 (1995).

26. P. Peled and D. Itzhak, Corros. Sci., 32, 83 (1991).

27. G. P. Chernova, T. A. Fedoseeva, L. P. Kornienko, and N. D. Tomashov, Surf. Technol., 13, 241 (1981).

28. J. H. Potgieter, J. Appl. Electrochem., 21, 471 (1991). 
29. N. J. Laycock and R. C. Newman, Corros. Sci., 39, 1771 (1997).

30. B. E. Wilde, in U.R. Evans Conference on Localized Corrosion, R. W. Staehle, B. F Brown, J. Kruger, and A. Agrawal, R. W. Staehle, Editors, p. 342, NACE, Houston, TX (1971).

31. K. K. Starr, E. D. J. Verink, and M. Pourbaix, Corrosion (Houston), 32, 47 (1976).

32. M. Pourbaix, Corrosion (Houston), 26, 431 (1970).

33. N. D. Tomashov and G. P. Chernova, in Passivity and Protection of Metals Against Corrosion, H. H. Uhlig, Editor, p. 82, Plenum Press, New York (1967).

34. J. A. Ali and J. R. Ambrose, Corros. Sci., 33, 1147 (1992).

35. G. S. Frankel, J. Electrochem. Soc, 145, 2186 (1998).

36. Y H. Kim, G. S. Frankel, and J. C. Lippold, ISIJ Int., Accepted. 